\title{
EFFECTIVENESS OF ALUMINUM-FOSETYL IN THE CONTROL OF EARLY NUTFALL OF COCONUT TREE DUE TO Phytophthora katsurae (Pythiaceae)
}

\author{
POHE J. ${ }^{1}$, DONGO B. K. ${ }^{1}$, N'GORAN N. ${ }^{2}$ \\ ${ }^{1}$ Laboratory of Plant Pathology and Biology-Department of Agriculture and Animal Ressources-National \\ Polytechnical Institute Félix Houphouet Boigny (INP-HB) PO BOX 1313 Yamoussoukro, Côte d'Ivoire. \\ ${ }^{2}$ Director of the Phytosanitary Department PALM-CI, Côte d'Ivoire.
}

\begin{abstract}
Early nutfall and bud rot due to Phytophthora katsurae (KO and CHANG) are the most important diseases of the coconut tree observed in recent years at the Assinie plantations of PALMINDUSTRIE Company, Côte d'Ivoire. Field investigations, conducted in 1983 by this revealed a high rate of nutfall $(50-70 \%)$ during the rainy season. The cutting of the coconut stands with rotten buds, as a way to control the spread of Oryctes sp., allowed to assess the number of dead tree over 139 and 89 ha of land for the hybrids and Grand West cultivars, respectively. In addition to those disease control measures proposed by the Company, comparison trials were systematically carried out using 2 fungicides : aluminum phosetyl at 3 dosages $(3.2 \mathrm{~g}, 4.8 \mathrm{~g}$ and $6.4 \mathrm{~g}$ of active ingredient/tree) and Ridomil at one dosage ( $3.125 \mathrm{~g}$ of active ingredient/tree). Thes fungicide were injected into the stem of the coconut every 3 months starting from December 1984. After 3 years of trial, the effectiveness of the 3 dosages of Al-Fosetyl over Ridomil in significantly reducing nutfall, even at low rates $(3.2 \mathrm{~g}$ of active ingredient per tree), was apparent. However, the technique still remains out of reach of most farmers because of lack of technical know-how. It appears therefore, that an improvement of the technique, so as to make it accessible to the farmers, is a necessity.
\end{abstract}

Keywords : Early nutfall, bud rot, coconut, Phytophthora katsurae, effectiveness of AluminumFosetyl.

\section{RESUME}

EFFICACITÉ DU PHOSÉTHYL D'ALUMINIUM DANS LA LUTTE CONTRE LA CHUTE DES NOIX IMMATURES DU COCOTIER CAUSÉ PAR Phytophthora katsurae (PYTHIACÉE)

La chute des noix immatures et la pourriture du coeur du cocotier causées par Phytophthora katsurae (KO et CHANG) sont les deux graves affections que connaît la cocoteraie d'Assinie en Côte d'Ivoire ces dernières années. D'après les observations en champs effectuées par la PALMINDUSTRIE en 1983, les chutes de noix ont atteint leur niveau maximal pendant la grande saison des pluies au cours de laquelle les sujets porteurs de grappes atteintes par la maladie ont perdu 50 à $70 \%$ de leurs noix. Les abattages des cocotiers morts, due à la pourriture du cœur, préconisés pour éviter la pullulation d'Oryctes sp. ont permis d'évaluer le nombre d'arbres morts à sur 139 ha pour les hybrides et de 89 ha pour la variété Grands Ouest Africains. En plus des mesures de contrôle d'urgence proposées par la PALMINDUSTRIE, des essais comparatifs ont été conduits avec deux fongicides systémiques : le Phoséthyl d'aluminium ou aliette (à $3.2 \mathrm{~g}, 4.8 \mathrm{~g}$ et $6.4 \mathrm{~g}$ de matière active par arbre) et le métalaxyl (Ridomil) à $3.125 \mathrm{~g}$ de matière active par arbre, injectés dans le stipe du cocotier tous les 3 mois à partir de décembre 1984. Après trois années 
d'expérimentation, le Phoséthyl-Al apparaît comme le fongicide le plus efficace contre ce fléau par comparaison au métalaxyl. Son injection dans le stipe du cocotier, même à faible dose (3.2 g de matière active par arbre), permet de réduire de façon significative les taux de chute des noix. Cependant, cette technique de lutte contre la maladie reste encore difficile à maîtriser par tous les planteurs de cocotier. Par conséquent, elle mérite d'être améliorée afin de la rendre plus accessible.

Mots clés : chute des noix immatures, pourriture du cœur, cocotier, Phytophthora katsurae, Phoséthyl d'Aluminium, réduction des taux de chutes.

\section{INTRODUCTION}

Coconut (Cocos nucifera L.) is one of the most important cash crops in Côte d'Ivoire. croping techniques ofn the plant have constantly been improved by the government since 1966. It was only in 1977 that fungus (Phytophthora katsurae) (KO and CHANG) attacks were described for the first time on the West African Tall (WAT) coconut variety) time in Assinie, in the sector south east of the Samo village (Quillec and Renard, 1984. The WAT is an early and highly productive coconut (4 to 5 t of dry copra/ ha) cultivar. Fungus attacks were revealed through damp bud rot and abnormal fall of immature (virtually ripe) nuts. Coconut bud rot rapidly spread to the Dwarf-WAT hybrids of the south eastern industrial plantations of PALMINDUSTRIE covering 3000 ha. The infection usually begins with a yellow spot around the floral parts, sometimes in the equatorial section of the nut. The centre of the spot becomes brown and purple with a yellow hallo and finally turns into dark. Nutfall occurs when the nut stalk is affected. Phytophtora katsurae found on coconut is located inside the leaf axle from where it attacks the surrounding fruits before spreading into the whole tree. From the leaf axle, it is capable of moving to the bud via wounds. Other symptoms included spear wilting of neighbouring young leaves and the death of rotten bud.
The investigation conducted in 1983 by the PALMINDUSTRIE company revealed a high level of nutfall (50-70\%) during the rainy season. In order to prevent the spread of Oryctes sp. from dead rotten coconut buds, several infected trees were cut off from a 139 ha plot for the hybrids and 89 ha for WAT. Due to important losses, some studies were carried out by I.R.H.O (Institute for Research on Oil Producing Plants) on the agent responsible for the disease. Emergency chemical control measures consisting in a systemic injection of fungicides into the stem were undertaken based on techniques proposed by PALMINDUSTRIE. The location of the fungus under leaf axle does not allow for a good contact of fungicides with the fungus.

Comparison trials on 2 fungicides Aluminium-Fosetyl (Aliette) and Metalaxyl (Ridomil) revealed that of Aluminium-Fosetyl was effective against both bud rot and early nut fall. Al-Fosetyl was recommended at $6.4 \mathrm{~g}$ of active ingredient in the control of the disease in all PALMINDUSTRIE plantations (Quillec and Renard 1984; De Franqueville and Renard, 1989). However, some questions still remain, such as response time, resilience effect, application dates and optimum rates. A more detailed study was undertaken to try to address those concerns. 
MATERIAL AND METHODS

\section{Experimental design}

The experimental design consisted of Fisher Blocks with 5 and 3 replicates for the comparison the of Al-Fosetyl rates and the effectiveness of Al-Fosetyl versus Ridomil respectively, with 100 coconut trees per treatment. The experiment covered an area of 16 ha, with experimental units containing 155 trees per ha, as a planting density. The plots were separated by non planted rows Fungicide application started in December 1984 and was repeated three months after the first treatment. Three rates $(3.2 ; 4.8$ and $6.4 \mathrm{~g}$ a.i per tree of Al-Fosetyl, corresponding to 4, 6 and $8 \mathrm{~g}$ of commercial product (CP) were selected based on the emergency control measures. The recommended $\mathrm{CP}$ rate for all the Pamindustrie Plantations was $8 \mathrm{~g}$ (6.4 g a.i (Quillec and Renard, 1984). The rates were compared with Ridomil (Ciba Geigy) at $25 \%$ (3.125 g a.i/tree). Details of the different combinations of treatments are as follows :

T0 : control, without fungicide

T1 : control with fungicide reference : (Ridomil at $3.125 \mathrm{~g}$ a.i/tree) T2 : Al-Fosetyl at $4 \mathrm{~g} \mathrm{CP/tree} \mathrm{(3.2}$ g a.i)

T3 : Al-Fosetyl at $6 \mathrm{~g} \mathrm{CP/tree} \mathrm{(4.8}$ g a.i)

T4 : Al-Fosetyl at $8 \mathrm{~g} \mathrm{CP} /$ tree $(6.4$ g a.i)

\section{Fongicide suspension Preparation}

Al-Fosetyl (Rhône Poulenc) (at 80 $\%$ a.i) was applied in a suspension form at a rate of $20 \mathrm{ml} /$ tree. Concentrations were adjusted so as to obtain an appli- cation rate of 4,6 and $8 \mathrm{~g} \mathrm{CP}$ per tree. The untreated control plots were similar in size as the treated ones. Ridomil was applied in the same manner as AlFosetyl. The experiments were carried out in the A2, C2, B7 and B12 plots in Assinie (Eastern Côte d'Ivoire) on Dwarf $x$ WAT hybrids. The plant materials were very heterogeneous with respect to origin, agronomical and morphological performances of the parents.

\section{Fungicide application}

Each fungicide was injected into the stem of the coconut tree through two holes dug downwards opposite each other. using an electrical drill fitted with a $12 \mathrm{~mm}$ diameter bit. Ten millilitre of the fungicide was injected into each hole using aa syringe. After injection, the hole was closed with a rubber bung and daubed with flintkote.

\section{Fungicide effectiveness monitoring}

Fungicide effectiveness monitoring included weekly phytosanitary checks during which the fallen nuts were counted. The rates of nutfall were calculated in the treated and control plots. Disease incidence reduction at each fungicide rate was calculated by subtracting the rates of nutfall in the treated from those obtained in the control plots. The weekly nutfall means were used to draw disease development curves for both treated and untreated plots and for the different trials set up at different dates under the same experimental conditions. Statistical analyses were also performed on the data. Analysis of variance (ANOVA) performed following data transformation using an arc sine function of the square root of the nutfall data because of differences in plot productivities. A one 
factor ANOVA was used to compare differences between treatments. Fisher PLSD, Scheffe F and Dunnett tests were used with a degree of freedom of 11 for the treated and non treated plots and 19 for fungicide rates (Pohé, 1996). Response time was taken as the time between treatment dates or that on which fungicide action became apparent.

Nutfall data allow, not only to assess the loss due to P.katsurae, but also, to look at disease developpement patterns as influenced by rainfall poatterns.

\section{RESULTS}

\section{Fungicide response time}

The curves (Fig. 1 to 4 ) reveal the three different phases of the disease that are generally known under natural conditions (Pohé, 1996) : 1) the curves of the treated and control plots show the same trend, with nearly the same nutfall levels ; 2) the second part shows nutfall curves for the treated plots, which clearly stand out from those of the untreated plots ; 3) the third part which represents the point of junction of the different curves corresponds to an increase in nutfall in the treated plots or a reduction in the non treated plots.

The curves also show that in December, the response time started one month after the first application and covered a period of up to 22 months (Fig.1). During that period, the rate of immature nutfall became lower than in the check plots. After this period, the level of nutfall became nearly the same in both treated and non treated plots. The same trend was also observed during the March, June and September months, with time varying according to application periods (Fig. 2, 3 and 4). If the response time started one month in december and march, it was less than a month in june and september. This period, which corresponds to the end of the resilient period, is also the natural disappearance of the disease, which was three to four weeks for treatments carried out during the December and September months (Fig.1 \& 4) and from seven to eight weeks for those conducted during the March and June months (Fig. $2 \& 3$ ). These observations were confirmed by the analysis of variance (after transformation). The differences between nutfall rates in both treated and untreated plots were significant from the fourth week for the treatments carried out during both December and September and eight weeks for those during the March and June months

\section{Resilient effect of the fungicides}

The period over which the second phase relative to the resilient effect intends to vary from one graph to another. The resilient effect of Al-Fosetyl appears to be shorter with the September treatment (Fig. 4). It was followed by the one in June (Fig. 3), March (Fig. 2) and December (Fig.1). A comparison using variance analyses on nutfall rate means after arc sin square roots transformation of the square root of the data are in lagreement with those observations. Thus, for the different treatments, resilient effect lasted 22, 18, 17 and 13 months for the December, March June and September treatments, respectively. 
Comparison of fungicide doses

After 24 months, it was observed that fungicide, at rates of $3.2 \mathrm{~g}, 4.8 \mathrm{~g}$ and $6.4 \mathrm{~g}$ a.i/tree had a significant effect nutfall, as compared to the control. However, there was no significant difference with treatment means.
Four, 6 and $8 \mathrm{~g} \mathrm{CP} /$ tree of AlFosetyl is effective when applied in the same period (Fig. 5). However, the rate of Ridomil used (3.125 g a.i) did not significantly reduce nutfall in our experimental conditions (tables 1 and 2 ).

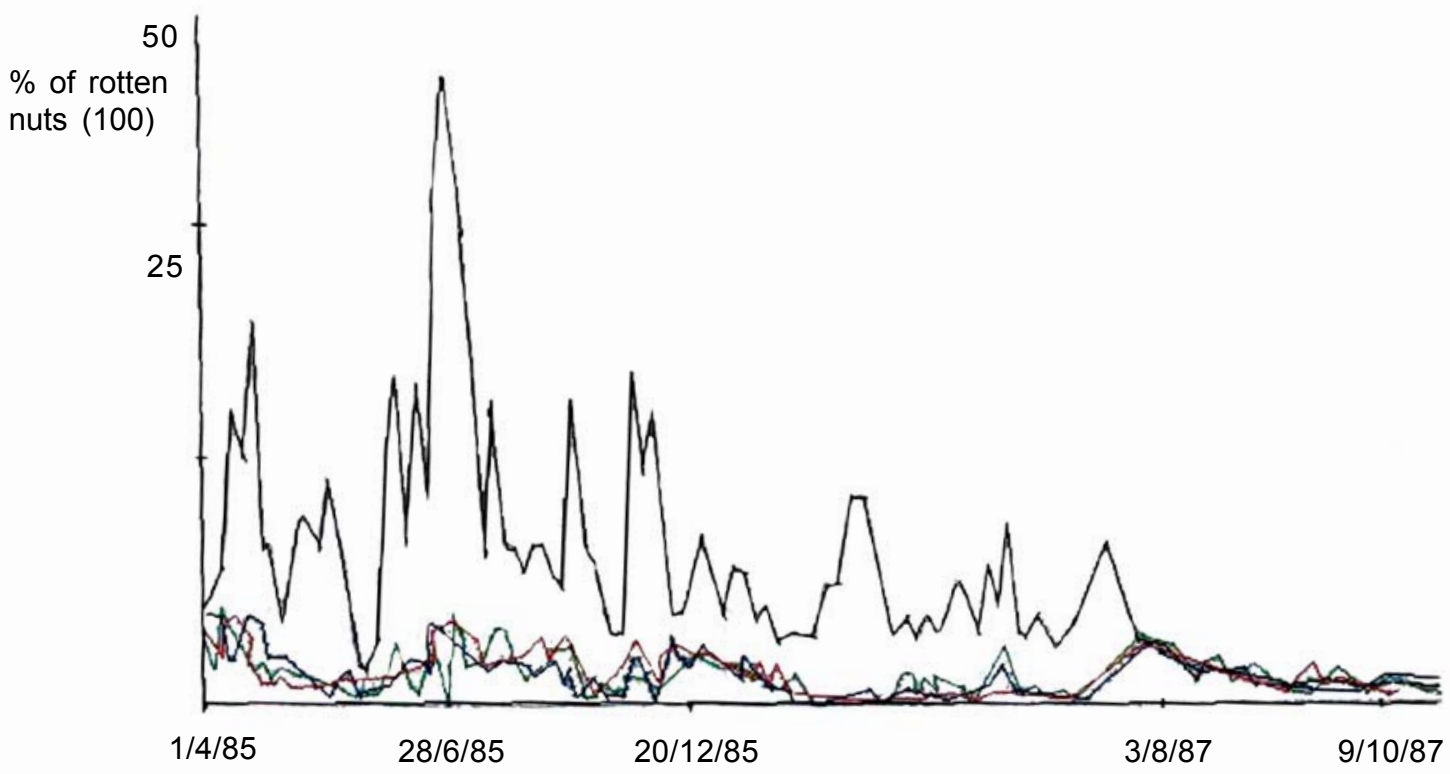

$1 \mathrm{~cm}$ for $5 \%$ of rotten nuts $-1 \mathrm{~cm}$ for 5 weeks

$\begin{array}{ll}- & \text { Check plots } \\ 4 \mathrm{~g} \mathrm{CP} / \text { tree } & 6 \mathrm{~g} \mathrm{CP} / \text { tree } \\ & 8 \mathrm{~g} \mathrm{CP} / \text { tree }\end{array}$

Figure 1 : Evolution of nutfall in coconut from the treated plots in December.

Evolution des chutes de noix de cocotier dans les parcelles traitées au mois de décembre. 


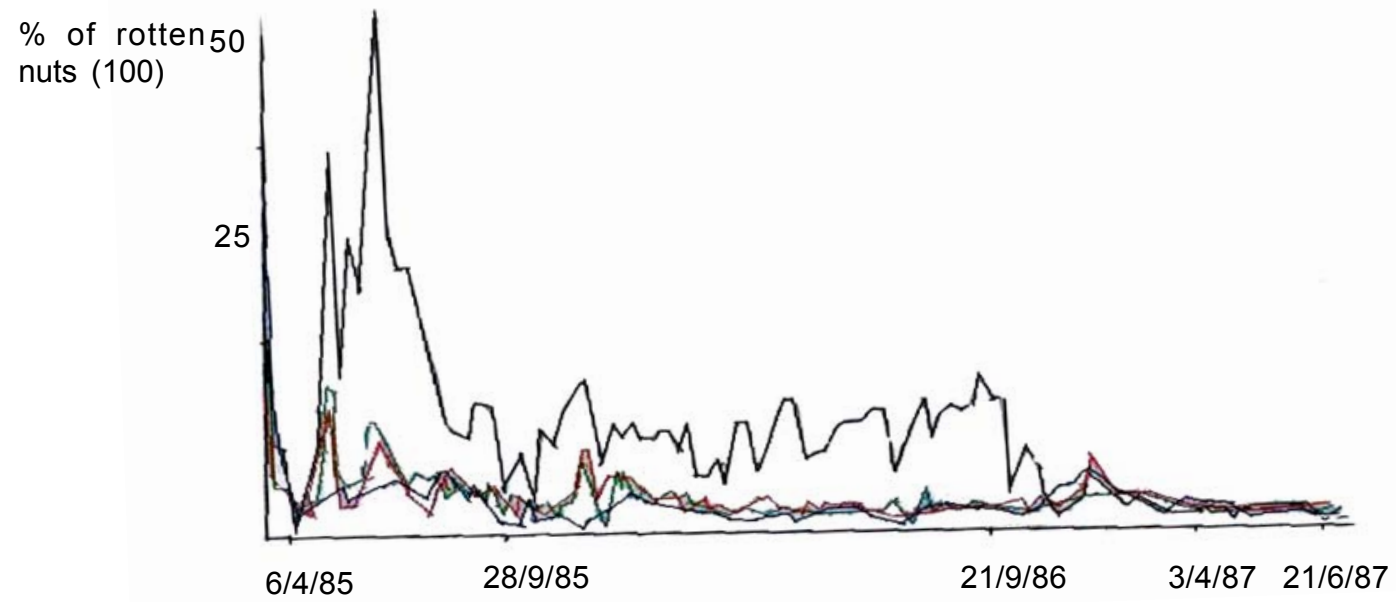

$1 \mathrm{~cm}$ for $5 \%$ of rotten nuts $-1 \mathrm{~cm}$ for 5 weeks

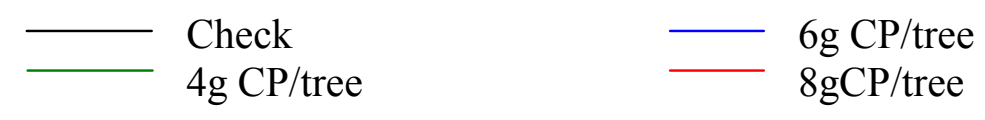

Figure 2 : Evolution of nutfall in coconut from treated plots in March.

Evolution des chutes de noix de cocotier dans les parcelles traitées au mois de mars.

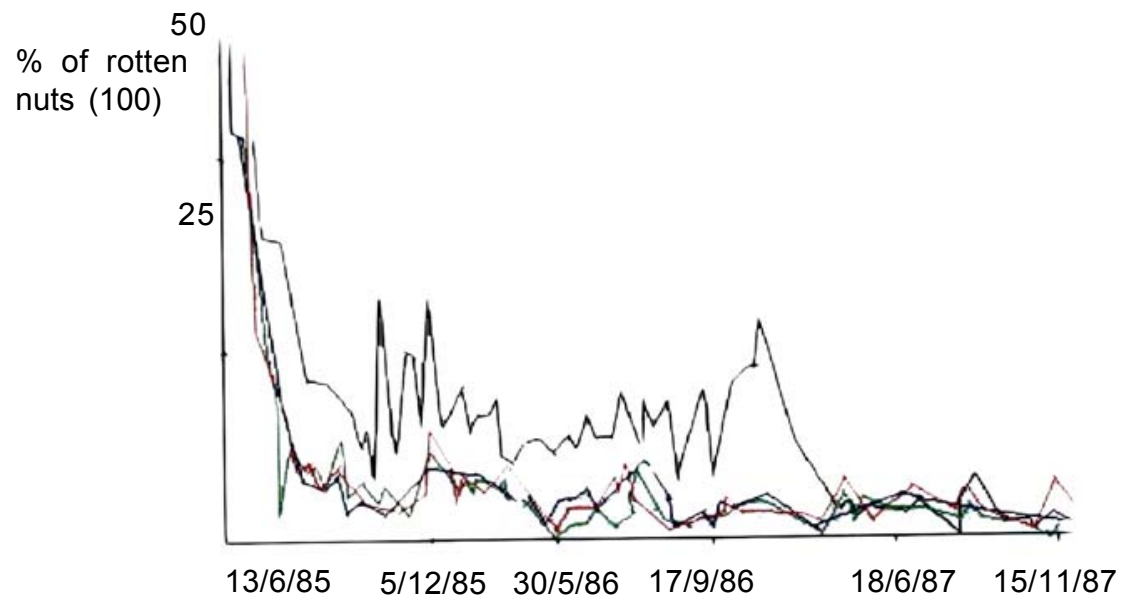

$1 \mathrm{~cm}$ for $5 \%$ of rotten nuts $-1 \mathrm{~cm}$ for 5 weeks

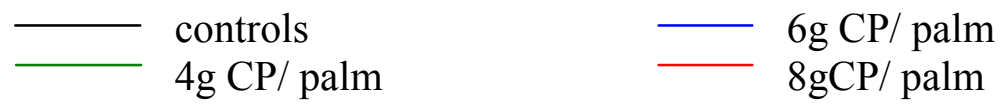

Figure 3 : Evolution of nut fall in coconut palm in plots treated in June.

Evolution des chutes de noix de cocotier dans les parcelles traitées au mois de juin. 


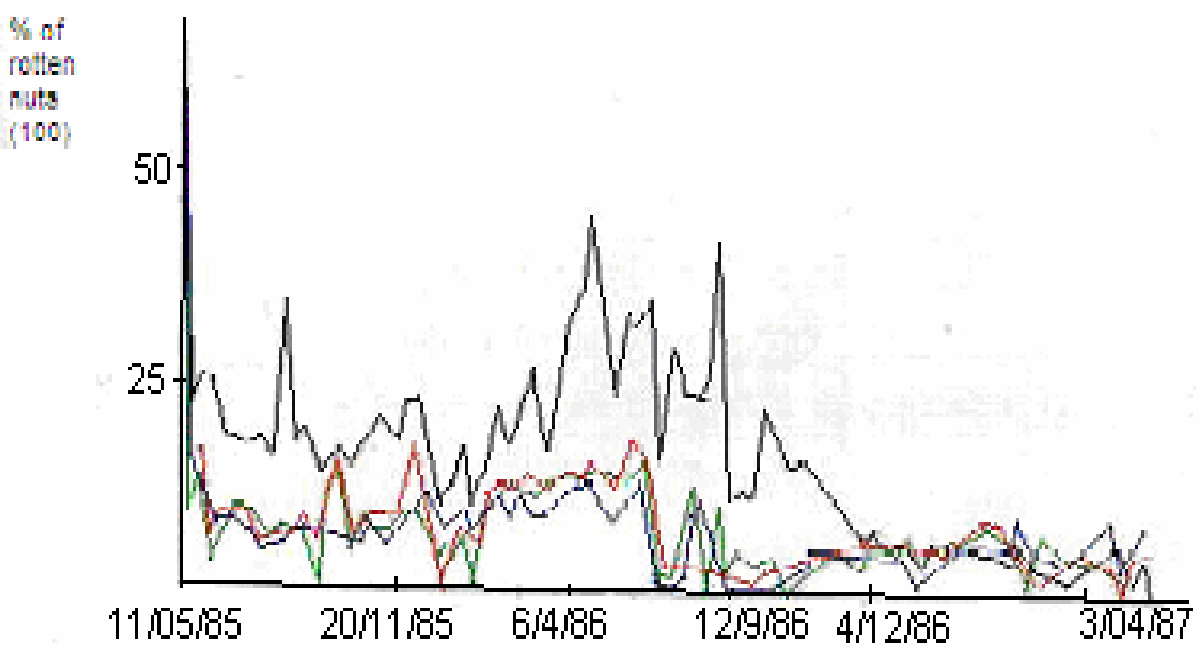

$1 \mathrm{~cm}$ for $5 \%$ of rotten nuts $-1 \mathrm{~cm}$ for 5 weeks

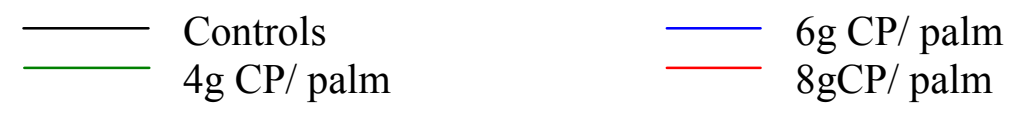

Figure 4 : Evolution of nut fall of coconut palm in plots treated in September.

Evolution des chutes de noix de cocotier dans les parcelles traitées au mois de septembre.

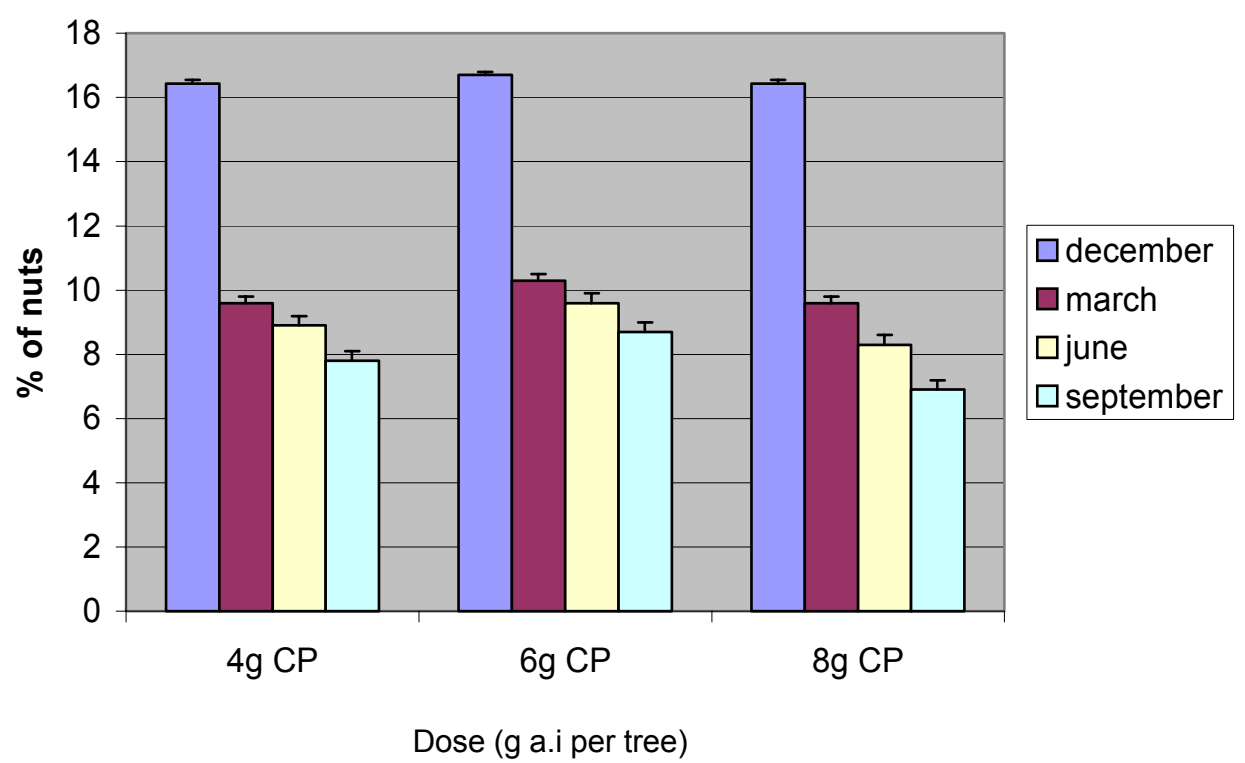

Figure 5 : Disease incidence reduction as a function of Al-Fosetyl rate and for different application periods.

Réduction de l'incidence de la maladie par rapport au témoin en fonction de la date d'utilisation du Al-Phoséthyl. 
Table 1 : Comparative effect of Al-Fosetyl and Metalaxyl, 8 months after application Effet comparatif du phoséthyl-Al et de Métalaxyl huit mois après application par injection dans le stipe du cocotier

\begin{tabular}{llccc}
\hline Treatment & Nutfall* & \multicolumn{3}{c}{ Nutfall due to $P$. katsurae } \\
\cline { 3 - 5 } & & Total & $\%$ & arcsin(square root of nutfall rate) \\
\cline { 3 - 5 } & & 736 & 8.38 & 16.74 \\
To & 8652 & 428 & 8.21 & 16.54 \\
T1 & 8889 & 222 & 2.60 & 8.82 \\
T2 & 8950 & 268 & 2.94 & 9.81 \\
T3 & 9358 & &
\end{tabular}

${ }^{*}$ means of 3 replicates

Table 2 : Statistical analyses of nutfall data.

Analyses statistiques des données relatives à la chute des noix.

\section{A ANOVA arcsin(square root of nutfall rate) transformation}

\begin{tabular}{lcccc}
\hline Origin of variance & df & Sum of squares & F. test & P Value \\
\hline Total & 11 & 192.600 & & \\
Replicates & 2 & 20.361 & 0.532 & $0.6048 \mathrm{~ns}$ \\
Treatments & 3 & 90.809 & 33.118 & $0.0004^{* *}$ \\
Residual & 6 & & & \\
\hline
\end{tabular}

ns nonsignificant

** significant

\section{B Comparison of means}

\begin{tabular}{lcccc}
\hline Treatment & Replicates & Means & $\begin{array}{c}\text { Standard } \\
\text { deviation }\end{array}$ & Standard error \\
\hline To & 3 & 16.74 & 2.08 & 1.201 \\
T1 & 3 & 16.547 & 2.314 & 1.336 \\
T2 & 3 & 8.823 & 2.015 & 1.163 \\
T3 & 3 & 9.817 & 1.159 & 0.669 \\
\hline
\end{tabular}

One Factor ANOVA X1: Treatments Y1: Nutfall

\begin{tabular}{lcccc}
\hline Comparison & $\begin{array}{c}\text { Differences } \\
\text { between means }\end{array}$ & Fisher PLSD & Scheffe F. test & Dunnett test \\
\hline T0 versus T1 & .193 & 3.657 & .005 & .122 \\
T0 versus T2 & 7.917 & $3.657 *$ & $8.309 *$ & 4.993 \\
T0 versus T3 & 6.923 & $3.657 *$ & $6.355^{*}$ & 4.366 \\
T2 versus T1 & -7.723 & $3.657 *$ & $7.908 *$ & 4.871 \\
T2 versus T3 & -.993 & 3.657 & .131 & .626 \\
T3 versus T1 & -6.73 & $3.657 *$ & $6.005 *$ & 4.244 \\
\hline
\end{tabular}


Evolution of the disease in relation with the rainy season

From the data collected on nutfall between 1985 and 1986, the following figure was drawn to show the evolution of the nutfall as compared to rains. There is some coincidence of peaks of rains and the disease. After the rains, some nutfall occurred. The intensity of the disease was not very linked to the quantity of the rains than the regularity and the overall rainy season. In 1986 marked by irregular rains, there was a low rate of nutfall in spite of some high level of rain registered on the month of may.

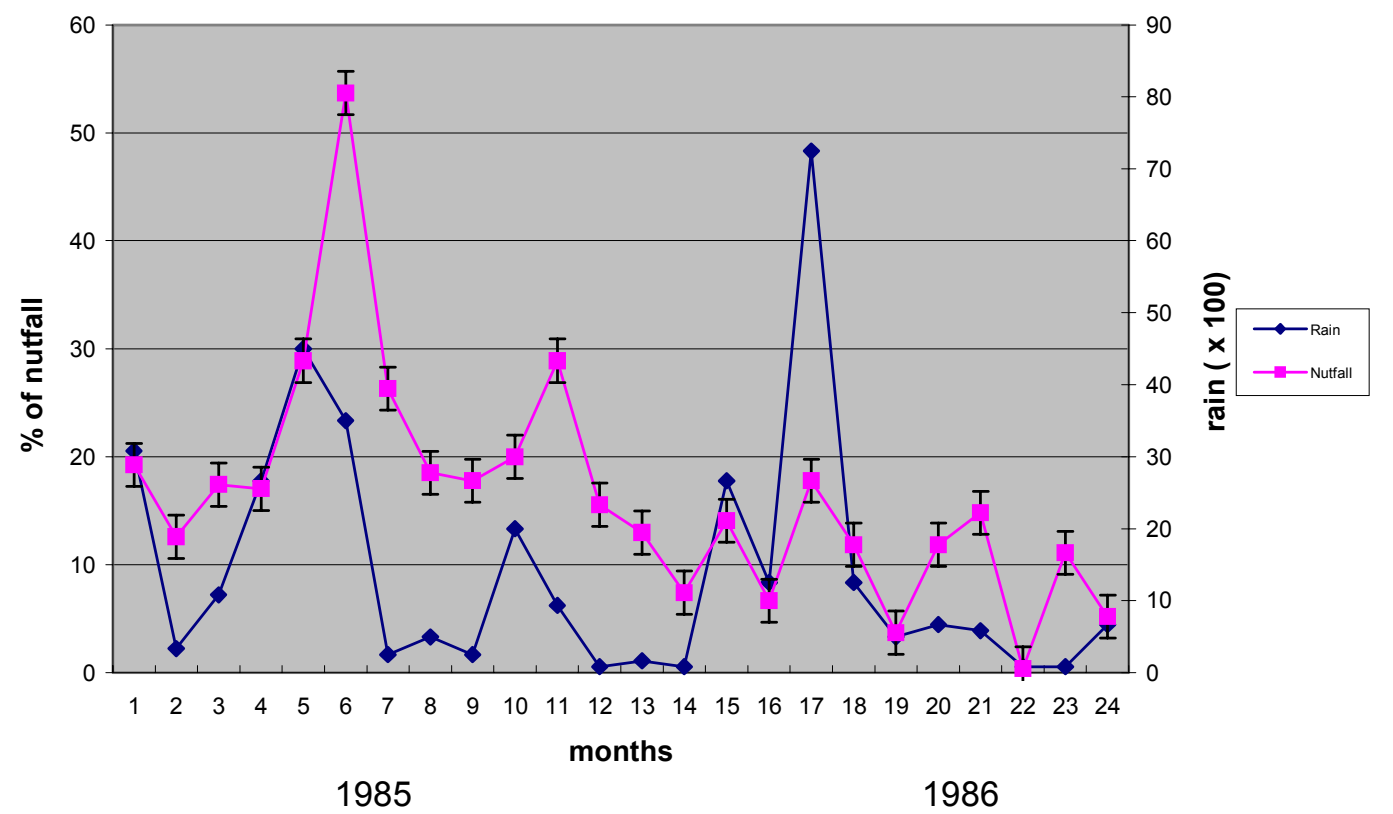

Figure 6 : Evolution of nutfall in coconut tree as a function of time and the rainy season from 1985 to 1986.

Evolution des chutes des noix de coco en fonction du temps en et de la pluviométrie entre 1985 à 1986.

\section{DISCUSSION}

Al-Fosetyl effect on nutfall at a rate of ( $3.2 \mathrm{~g}, 4.8 \mathrm{~g}$ and $6.4 \mathrm{~g}$ a.i/tree) was revealed after injection into the coconut stem. The time at which the effect is observed varied according to date of application and will last as long as the fungicide is applied during the dry period of the year, especially in December. It should be noted that December and September months correspond to dry periods (long and short dry seasons, respectively) and those from march to June to rainy the periods in the South of Côte d'Ivoire. The disease reached a peak from June to July during the rainy period (Pohé, 1992; Pohé, 1996). After the rain season, nutfall occured following a period corresponding to the incubation of the fungus and the onset of the disease. Rain appears to be an important climatic factor responsible for the onset of the disease. For this reason, treatments with an endotherapeutic product injected into the tissue at the beginning of the rainy season must be recommended. In fact, the observations revealed the contrary, given that treatments in the dry season resulted in shorter response time than 
those carried out in the rainy season. This shows the necessity to take into account, it appears necessary to take into account the resilient effect of the fungicide when choosing treatment dates. The physiology of the coconut tree, especially on hybrid WAT $x$ Dwarf of Malasia (PB 121) showed that it has a very important mineral absorption in an environment that is getting dryer and dryer (Daniel et al., 1991). The needs of plants, for nutrients, particularly tissue under grot growth (such as nuts) are very high due to loss through evapotranspiration. Generally the December month is very dry due to the Harmattan, which is a dry and cool wind blowing from the North to the South of the Country causing the coconut plant to undergo important dehydration. This compels the plant to pump large quantities of nutrients, and water, which is another argument that shows that this period is best suited for of Al-Fosetyl Application. It was also shown that light intensity was an important factor governing the biosynthesis of phenolic compounds (Ali Bert et al., 1977; Amrhein and Zeink, 1977; Bompeix et al., 1981). Al-Fosetyl acts through such substances in the coconut plant (Bompeix, 1992). One can notice that during the rainy season in the tropics, sun light intensity is lower, therby, reducing the liberation of the phenolic compounds and the efficacy of the fungicide. Aluminum-Fosetyl was found to significantly reduce the incidence of the disease. Concerning the mechanism of action of the fungicide, it was found to have a direct in vivo action, but such action is controversial or very weak (Bompeix and Saindrenan,1984). It is highly specific in that it induces plant host resistance (Bompeix et al., 1980; Medath et al., 1992), which is a long term resistance in the case of the coconut tree.

\section{CONCLUSION}

Early nutfalll and bud rot are the most important diseases observed in recent years in Côte d'Ivoire on the coconut tree. The diseases can be controlled by the injection of Al-Fosetyl in the stem of the coconut tree, as proposed by I.R.H.O (Quillec and Renard, 1984). Because of its chemoprotective action, it induces some resistance in the tree that is characterized by a reduction in the rate of progress of the disease for at least 24 months, particularly when it is used in December, a dry and cool period of the year. During this period, the PB121 hybrid had had the best mineral absorption. Although our results are significant concerning the efficacy of Al-Fosetyl, they can only be considered as emergency measures. More studies need to be undertaken to see if the injection of Al-Fosetyl is financially and technically feasible many farmers. The cost-effectiveness of the application of the fungicide has already been proven. However, the mastering of the technique is not achieved by many farmers This is the reason why other measures such as the roots absorption (De Franqueville, 1992) need to be investigated in order to make the use of this fungicide, which efficacy is well known, accessible to many farmers.

\section{REFERENCES}

AMRHEIN, (N.) and ZEINK, (M.H.) (1977). Metabolism of phenylpropanoid compounds.Physiol. Veg. 15: 251-260.

ALI BERT, (G.), RANJEVA, (R.) et BOUDET, (A.) (1977). Organisation subcellulaire des 
voies de synthèse des composés phénoliques. Physiol. Vég. 15 : 279-301.

BOMPEIX, (G.) (1992). Migration of phosphoric acid in the coconut. Coconut Phytophthora workshop, Indonesia-Manado, October 2630. Pages 169-170.

BOMPEIX, (G.) and SAINDRENAN, (P.) (1984). In vitro Antifungal Activity of Al-Fosetyl and phosphorous Acid on Phytophthora species. Fruits Vol. 39, Nº12 1984: 777786.

BOMPEIX, (G.), FETTOUCHE, (F.) et SAINDRENAN, (P.) (1981). Mode d'action du Phoséthyl-Al. Phytiatrie-Phytopharmacie $30:$ 257-272.

BOMPEIX, (G.), RAVISE, (A.), RAYNAL, (G.), FETTOUCHE, (F.) et DURAND, (M.C.) (1980). Modalités de l'obtention des nécroses bloquantes sur feuilles détachées de tomate par l'action du tris-O-éthyl phosphonate d'aluminium (phoséthyl d'aluminium), hypothèse sur son mode d'action in vivo. Phytiatrie-Phytopharmacie $29: 241-256$

DANIEL, (C.), ADJE, (I.) et VIHOUNDJE, (F.) (1991). Comportement des cocotiers hybrides nain $x$ grand en climat sec et sous irrigation. Oléagineux 46 (1) : 13-22.

De FRANQUEVILLE, (H.) et RENARD, (J.L.) (1989). Intérêt du Phoséthyl-Al dans la lutte contre le Phytophthora du cocotier. Oléagineux 44 (7) : 351-358.

MEDAHT (A.), BOUZI (N.), LEPOI- VRE(P.) SEMAL (J.) (1992). Chémoprotection indirecte contre les champignons phytopathogènes : concept et applications. Cahiers Agricultures $1: 47-54$.

POHE, (J.) 1992. Components of coconut susceptibility to Phytophthora heveae attacks in Côte d'Ivoire. Coconut Phytophthora workshop Indonesia-Manado, October 2630. Pages 111-115.

POHE, (J.) 1996. Contribution à l'étude de la pourriture du cœur et de la chute des noix immatures du cocotier dues à Phytophthora katsurae (KO et CHANG) en Côte d'Ivoire. Thèse de Doctorat. Institut National Agronomique Paris-Grignon. 179 pages.

QUILLEC, (G.) et RENARD, (J.L.) (1984). La pourriture à Phytophthora du cocotier. Oléagineux Vol. $39 \mathrm{~N}^{\circ} 3$ : 143-147. 